\title{
Analysis of Groundwater Quality Surrounding Municipal Solid Waste Landfill: Banyuurip Landfill, Magelang, Indonesia
}

\author{
Mochamad Arief Budihardjo ${ }^{1,}$, Purwono $^{1}$, and Annisa Selfi Nugraheni ${ }^{1}$ \\ ${ }^{1}$ Department of Environmental Engineering, Universitas Diponegoro, Jl.Prof.H.Soedarto, \\ S.H.Tembalang, Semarang, Indonesia
}

\begin{abstract}
Banyuurip landfill generates leachate containing suspended and dissolved matter, including some heavy metals, a result of waste degradation and decomposition of organic materials. Leachate can infiltrate the soil then contaminate groundwater. Once the leachate infiltration reaches the soil and groundwater, it will contaminate the surrounding environment. In this study, the contamination of leachate into ground water was investigated by measuring the concentration of Manganese (Mn), Iron $(\mathrm{Fe})$ and Free Ammonia $\left(\mathrm{NH}_{3}-\mathrm{N}\right)$ in leachate and dug wells surrounding the landfill. The concentration of $\mathrm{Mn}, \mathrm{Fe}$ and $\mathrm{NH}_{3}-\mathrm{N}$ in leachate was found to be $5.42 \mathrm{mg} / \mathrm{L}, 6.16 \mathrm{mg} / \mathrm{L}$, and $1652 \mathrm{mg} / \mathrm{L}$, respectively. The concentration in the surrounding dug wells located within $500 \mathrm{~m}$ from the landfill varied from $0.00-0.86 \mathrm{mg} / \mathrm{L}$ for free ammonia, $0.00-0.31 \mathrm{mg} / \mathrm{L}$ for total $\mathrm{Fe}$, and $0.00-0.26 \mathrm{mg} / \mathrm{L}$ for total $\mathrm{Mn}$. The concentration of Mn, $\mathrm{Fe}$ and $\mathrm{NH}_{3}-\mathrm{N}$ decrease with increasing distance between the landfill and wells.
\end{abstract}

\section{Introduction}

Solid waste landfill servicing the Magelang municipality is located at Banyuurip, Magelang. Total domestic solid waste received by the Banyuurip landfill is about 4.5 tonne/day, which consists of organic matter, paper, plastic, metal, rubber, wood, glass and other materials. The composition is dominated by approximately $70 \%$ organic matter and $10 \%$ of plastic.

Banyuurip landfill generates leachate containing suspended and dissolved matter as a result of waste degradation and decomposition of organic materials, consisting of both organic and inorganic materials. The organic matter includes hydrocarbons and humic acid, and the inorganic matter include calcium, magnesium, natrium, kalium, ammonium, iron, manganese, chloride, sulphate, cadmium, chromium, copper, lead, nickel and zinc [1].

The primary substances found in leachate are $\mathrm{Mn}, \mathrm{Fe}$ and $\mathrm{NH}_{3}-\mathrm{N}$. Manganese and $\mathrm{Fe}$ could lead to turbidity, colour and bad water taste, while $\mathrm{NH}_{3}-\mathrm{N}$ can cause odour and different tasting water [2]. Leachate can infilter through soil causing contamination to

\footnotetext{
*Corresponding author: m.budihardjo@,ft.undip.ac.id
} 
groundwater. Once the leachate infiltration reaches a well, it will also pollute the well water [3].

Landfill leachate quality is affected by the composition of the waste and meteorological conditions, such as rainfall, landfill operation, chemical and biological reactions during the decomposition processes [4]. The leachate may seep into the soil and reach the groundwater through the landfill liner which consists of compacted clay [5]. The groundwater contamination can be evaluated by performing water quality testing on a sample of wells surrounding the landfill [6].

In this study, infiltration of three leachate parameters, $\mathrm{Mn}, \mathrm{Fe}$ and $\mathrm{NH}_{3}-\mathrm{N}$, into the surrounding dug wells located in area within $500 \mathrm{~m}$ from the landfill are investigated. The concentration of these parameters were analyzed and results compared with the distance between landfill and the dug wells in which the samples were taken.

\section{Methods}

This study was undertaken at Banyuurip Landfill, Magelang, Central Java, Indonesia (Figure 1). The samples were collected from leachate collection outlets and dug wells owned by local residents located no more than $500 \mathrm{~m}$ from the landfill. The data collected from the site includes coordinates of well, diameter of the wells, water table, and the well distance from the landfill.

A water sample collected from the dug wells was analyzed in the laboratory to determine the concentration of total $\mathrm{Mn}$, total $\mathrm{Fe}$ and $\mathrm{NH}_{3}-\mathrm{N}$. Geology and hydrogeology conditions, as well as porosity and permeability of the soil at both locations were also determined. Laboratory data was analyzed focusing on $\mathrm{Mn}, \mathrm{Fe}$ and $\mathrm{NH}_{3}-\mathrm{N}$.

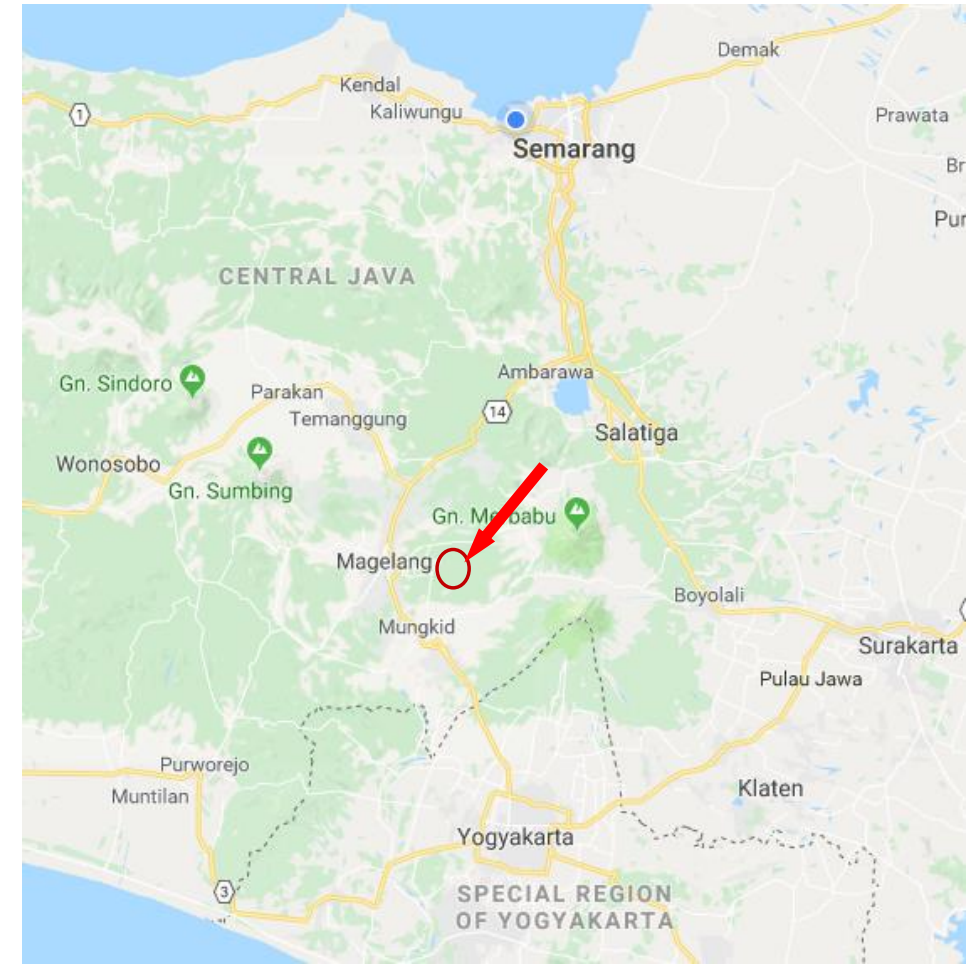

Fig. 1. Location of Banyuurip Landfill, Magelang. 


\section{Results and Discussion}

\subsection{Landfill Leachate Quality}

Banyuurip landfill leachate appearance had a brown to black color, contained a lot of total suspended solid matter and had a bad odor, as a result of high concentration of $\mathrm{NH}_{3}-\mathrm{N}$. Table 1 shows Banyuurip landfill leachate characteristics on total $\mathrm{Mn}$, total $\mathrm{Fe}$ and $\mathrm{NH}_{3}-\mathrm{N}$ parameters.

Table 1. Leachate Quality

\begin{tabular}{|c|c|c|}
\hline No & Parameter & $\begin{array}{c}\text { Concentration } \\
(\mathrm{mg} / \mathrm{L})\end{array}$ \\
\hline 1 & Total $\mathrm{Mn}$ & 5.42 \\
\hline 2 & Total Fe & 6.16 \\
\hline 3 & $\mathrm{NH}_{3}-\mathrm{N}$ & 1652 \\
\hline
\end{tabular}

Concentrations of all three parameters in the landfill leachate were high, with $\mathrm{NH}_{3}-\mathrm{N}$ being most abundant with up to $1652 \mathrm{mg} / \mathrm{L}$. $\mathrm{NH}_{3}-\mathrm{N}$ in the leachate can be traced back to solid waste characteristics, $70 \%$ of solid waste being organic material. The main composition of the organic matter is Carbon $(\mathrm{C})$, Hydrogen $(\mathrm{H})$, Oxygen $(\mathrm{O})$ and Nitrogen (N) [1], and most of the nitrogenous compounds in the leachate are in the form of free ammonia. The leachate was highly concentrated with free ammonia.

Total $\mathrm{Fe}$ in the Banyuurip landfill leachate was $6.16 \mathrm{mg} / \mathrm{L}$, which was higher than the drinking water quality threshold of $0.5 \mathrm{mg} / \mathrm{L}$. Iron in the landfill leachate comes primarily from metal waste which comprises of about $1-2 \%$ of total waste sent to the Banyuurip landfill. Total $\mathrm{Mn}$ in the leachate was $5.42 \mathrm{mg} / \mathrm{L}$. Similar to Fe, Mn also comes from metal waste dumped at the landfill.

\subsection{Groundwater Quality}

Total Mn concentration in the surrounding wells was between $0.00-0.26 \mathrm{mg} / \mathrm{L}$. Total Mn was found in almost all wells. The relationship between the distance and total $\mathrm{Mn}$ concentration is shown in Figure 2. 


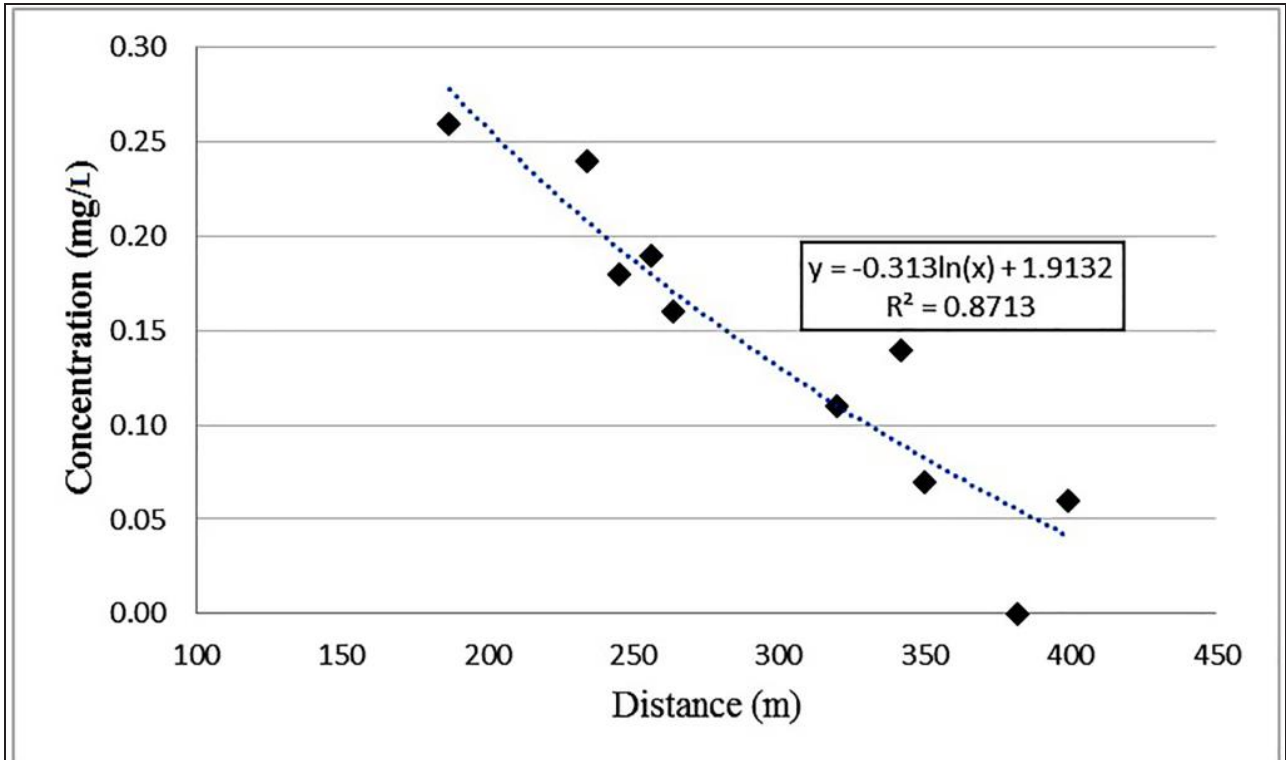

Fig. 2. Relationship between landfill-well distance and Mn concentration

The $\mathrm{R}^{2}=0.8713$ suggests that there is a very strong and significant correlation between landfill-to-well distance and total Mn concentration. When the distance between the landfill and dug well increases, the total Mn concentration decreases. The Mn in the soil and physio-chemical-biological conditions could alter Mn concentration at the sub-surface. Manganese concentration in the groundwater above $0.10 \mathrm{mg} / \mathrm{L}$ can cause color, odor or change of water taste. Moreover, very high concentrations of $\mathrm{Mn}$ is toxic to the neural system and may trigger infant mortality [7].

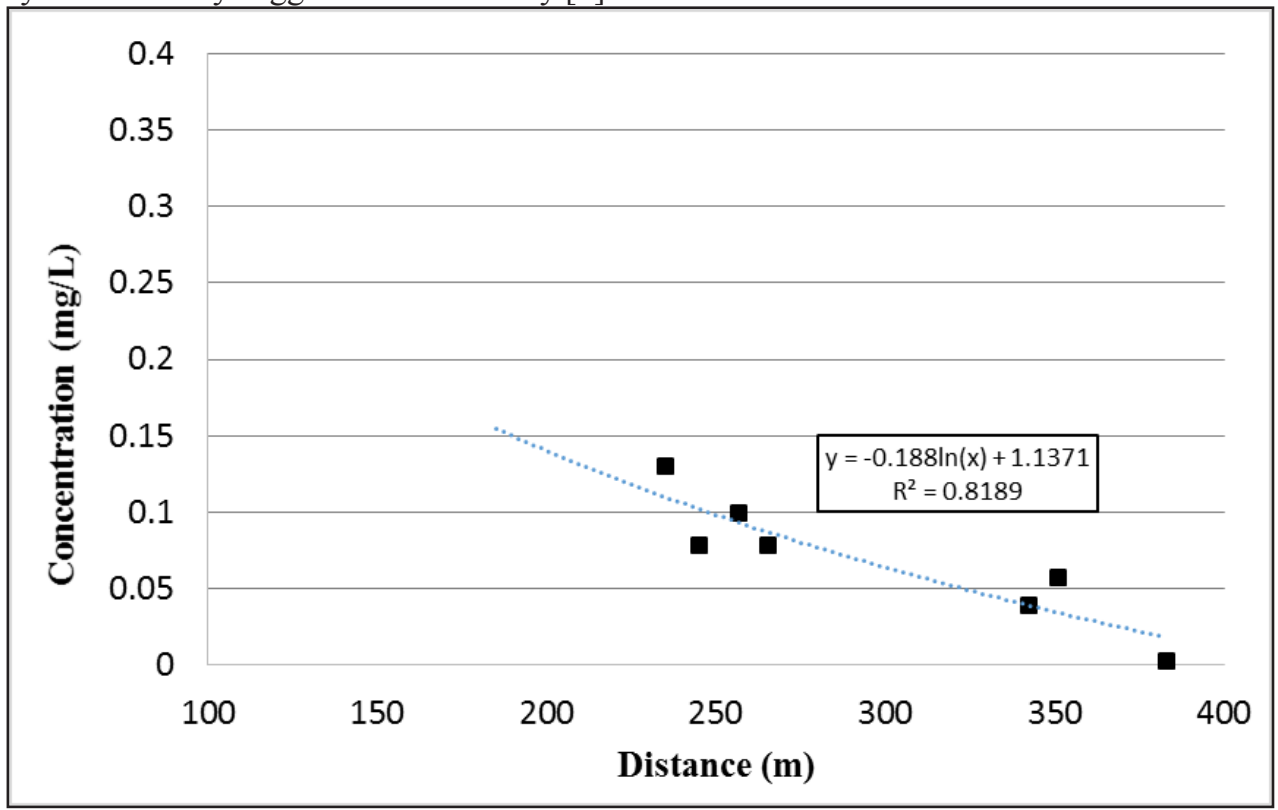

Fig. 3. Relationship between landfill-well distance and Fe concentration 
Iron is classified as a secondary pollutant because its effects are more related to aesthetics rather than human health concerns [8]. When the concentration of $\mathrm{Fe}$ is high, it will generate a bad taste in the water, yellow color, stimulate growth of Fe bacteria and turbidity. Total Fe concentration in the dug wells are between $0.00-0.31 \mathrm{mg} / \mathrm{L}$. In dug wells located more than $350 \mathrm{~m}$ from the landfill, the concentration of Fe is very low and almost undetectable in the groundwater samples. The relationship between distance and total Fe concentration is illustrated in Figure 3.

As seen in Figure 3, the $\mathrm{R}^{2}=0.8189$ suggests that there is a strong and significant relationship between landfill-to-well distance and total Fe concentration. The concentration of $\mathrm{Fe}$ in the dug wells decreases as distance increases between the landfill and dug well. A correlation coefficient of 0.8189 indicates that about $76.73 \%$ of the total $\mathrm{Fe}$ in the groundwater can be explained by the distance variable. The remaining $28.11 \%$ is affected by other factors.

The $\mathrm{NH}_{3}$-Nconcentration ranging from 0.00 to $0.86 \mathrm{mg} / \mathrm{L}$, is lower than the drinking water standard of $1.5 \mathrm{mg} / \mathrm{L}$. The relationship between the distance and $\mathrm{NH}_{3}-\mathrm{N}$ concentration is plotted in Figure 4 . The $\mathrm{R}^{2}=0.8844$ suggests that the concentration of $\mathrm{NH}_{3}$ $\mathrm{N}$ in the groundwater is mostly affected by the distance variable. Concentration of $\mathrm{NH}_{3}-\mathrm{N}$ above the standard, results in water odor and unpleasant taste. Very high ammonia levels can cause damage to cells and body membrane irritation [9].

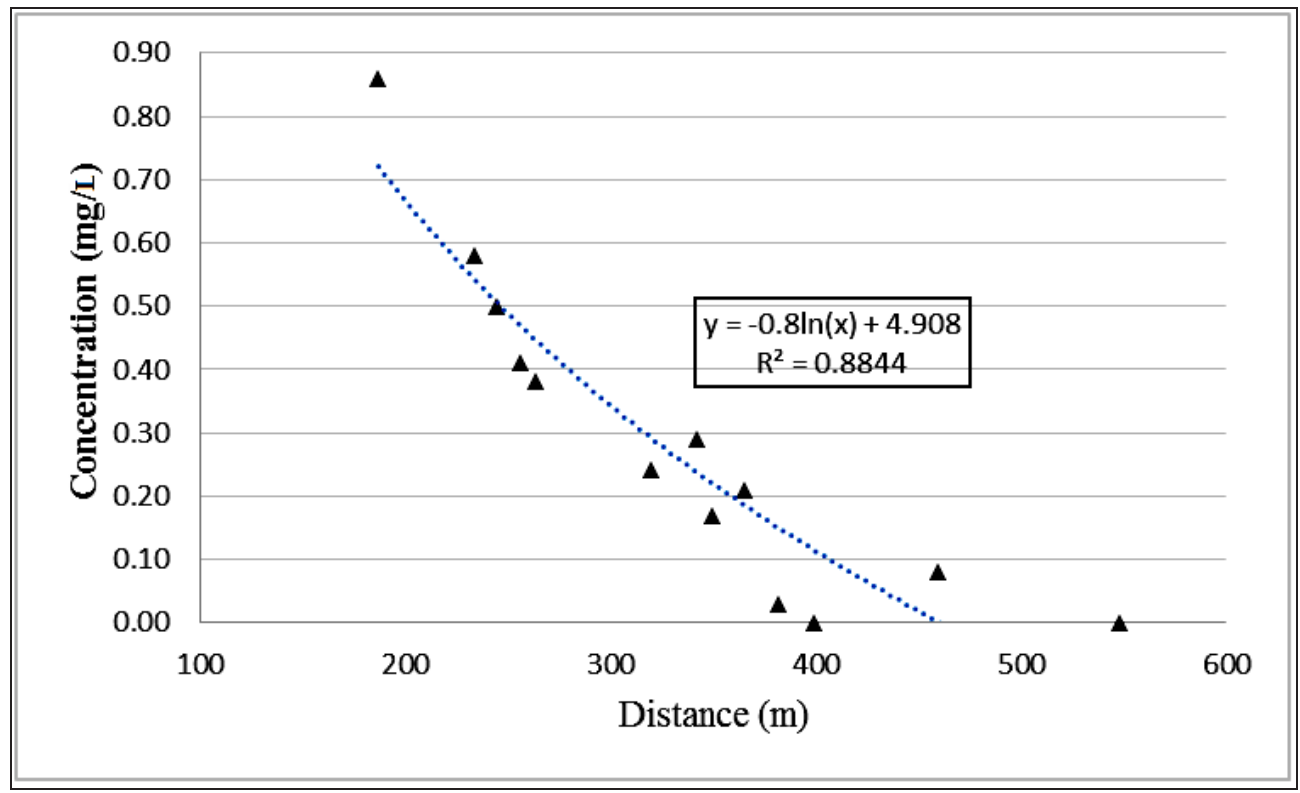

Fig 4. Relationship between landfill-well distance and $\mathrm{NH}_{3}-\mathrm{N}$ concentration

\section{CONCLUSION}

This study was performed to investigate potential migration of $\mathrm{Mn}, \mathrm{Fe}$ and $\mathrm{NH}_{3}-\mathrm{N}$ from landfill leachate into the groundwater. The concentration of these parameters in the ground water were determined by taking water samples from dug wells located within $500 \mathrm{~m}$ from the landfill. The concentration of $\mathrm{Mn}, \mathrm{Fe}$ and $\mathrm{NH}_{3}-\mathrm{N}$ in the leachate was found to be 5.42 $\mathrm{mg} / \mathrm{L}, 6.16 \mathrm{mg} / \mathrm{L}$ and $1652 \mathrm{mg} / \mathrm{L}$. The concentration of these three parameters in the dug wells varied depending on the distance between the dug wells and landfill. The Mn concentration ranged from 0 to $0.26 \mathrm{mg} / \mathrm{L}$, the $\mathrm{Fe}$ and $\mathrm{NH}_{3}-\mathrm{N}$ concentration are 0 to 0.31 
$\mathrm{mg} / \mathrm{L}$ and 0 to $0.86 \mathrm{mg} / \mathrm{L}$, respectively. The concentration of all these three parameters in the ground water decreases with increasing distance from the landfill.

\section{References}

1. R.B. Brennan, M.G. Healy, L. Morrison, S. Hynes, D. Norton, E. Clifford, Waste Manage. 55 (2016).

2. M. Loizidou, E. Kapetanios, Sci. Total Environ. 128, 1 (1993)

3. M.M.A. El-Salam, G.I. Abu-Zuid, J. Adv. Res. 6, 4 (2015)

4. R. Slezak, L. Krzystek, S. Ledakowicz, Waste Manage. 43 (2015)

5. M.A. Budihardjo, Adv. Mater. Sci. Eng. (2016).

6. S. Singh, N.J. Raju, W. Gossel, P. Wycisk, Arabian J. Geosci. 9, 2 (2016).

7. L.A. Schaider, , R.A. Rudel, , J.M. Ackerman, , S.C. Dunagan, J.G. Brody, Sci. Total Environ. 468 (2014)

8. S.K. Sharma, J. Kappelhof, M. Groenendijk, J.C. Schippers, J. Water Supply Res. T. 50, 4 (2001)

9. I.M Suffet, D. Khiari, A. Bruchet, Water Sci. Technol. 40, 6 (1999) 